\title{
Nutritional Composition, Mineral Content and Antioxidant Properties of Unpolished Red Rice Cultivars of Assam, India
}

\begin{abstract}
Background: Assam is a rich source of different types of colored rice cultivars. Very few colored rice cultivars are studied regarding nutritional and phytochemical properties. The objective of present study was to assess the nutritional composition and antioxidant properties of traditional red rice cultivars of Assam.

Methods: Ten different red rice cultivars were collected for the study. The unpolished rice grains were analysed for proximate composition, mineral content, total phenolic, flavonoid content and DPPH free radical scavenging activity.

Result: Amylose content was found to be low in the red rice cultivars. The carbohydrate and crude protein content varied significantly among the red rice cultivars. The studied cultivars were found to be good source of Fe, $\mathrm{Mn}$ and $\mathrm{Zn}$. Highest total phenolic (1357.22 mg $1100 \mathrm{~g})$ and flavonoid content $(896.37 \mathrm{mg} / 100 \mathrm{~g})$ were found in the Hal aus, whereas the lowest value for total phenolic (336.49 mg/ $100 \mathrm{~g}$ ) and flavonoid content $(127.51 \mathrm{mg} / 100 \mathrm{~g})$ were observed in Basanta bahar. Antioxidant capacity of colored rice varieties ranged from 33.33 to $84.24 \%$ for DPPH radical scavenging activity. The red rice cultivars contain a significant amount of nutrients and antioxidants including phenolic and flavonoids.
\end{abstract}

Key words: Antioxidant activity, Minerals, Red rice cultivar, Total flavonoids, Total phenols.

\section{INTRODUCTION}

Rice (Oryza sativa L.) is the staple food of Assam, Northeastern state of India. Rice plays a pivotal role in the sociocultural life of people of Assam and also state economy. Although widely consumed as white rice, there are many special cultivars of colored rice that is characterized by its grain with red, black or dark purple color covering in different layers of the pericarp, seedcoat and aleurone. These cultivars are grown in upland, lowland and deep-water conditions of Assam (Chaudhary, 2003). Anthocynain compounds, a subclass of flavonoids are responsible for the color of grain (Abdel-Aal et al. 2006, Yawadio et al. 2007). Colored rice contains higher amounts of proteins, fiber, vitamins and other micro nutrients like iron, zinc (Itani et al. 2002, Suzuki et al. 2004).

Phenolic compounds play an important role in decreasing the oxidative stress by scavenging free radicals (Ti et al. 2014). The phenolic compounds in rice are found in the soluble and insoluble (bound) form, with the soluble form representing $38 \%$ to $60 \%$ of the total polyphenols content in light brown rice grains and around $81 \%$ in red and black pericarp color grains (Mira et al. 2009). The type and concentration of polyphenols in the rice grain vary according to different genotypes and to the pericarp color. Colored rice varieties contains higher amount of total phenolics, flavonoids and antioxidant activity than those of light colored varieties, such as white varieties (Walter et al. 2013 and Shao et al. 2014).

Very few studies were reported on the colored rice cultivars of Assam, India (Saikia et al. 2012, Mudoi and Das, $2018,2019)$. In this regard, different cultivars of red rice of Assam were investigated to determine the nutritional and antioxidant properties.
Department of Biochemistry and Agricultural Chemistry, Assam Agricultural University, Jorhat-785 013, Assam, India.

Corresponding Author: Tiluttama Mudoi, Department of Biochemistry and Agricultural Chemistry, Assam Agricultural University, Jorhat-785 013, Assam, India.

Email: tiluttamamudoi@yahoo.co.in

How to cite this article: Mudoi, T. and Das, P. (2022). Nutritional Composition, Mineral Content and Antioxidant Properties of Unpolished Red Rice Cultivars of Assam, India. Asian Journal of Dairy and Food Research. DOI: 10.18805/ajdfr.DR-1751.

Submitted: 07-06-2021 Accepted: 20-12-2021 Online: 29-01-2022

\section{MATERIALS AND METHODS}

\section{Collection of samples}

Ten different red pigmented rice cultivars were collected from Regional Agricultural Research station, Karimganj, Assam in the year 2015. Rata Boro, Koujapuri, Makhan Boro, Kaya Boro, Kolaboro are grouped as spring or summer rice and Basantabahar, Dadratai, Binnapali, Buriamakra, Hal aus are grouped as autumn rice.

\section{Processing of rice grains}

Rice grains were de-husked using a de-husker (Satake Corporation, Hiroshima, Japan). The unpolished rice grains were ground to flour and used for further analysis.

\section{Amylose content}

The amylose content was estimated according to Sowbhagya and Bhattacharya, 1979.

\section{Proximate composition analysis}

Moisture content, carbohydrate content, crude protein, crude 
Nutritional Composition, Mineral Content and Antioxidant Properties of Unpolished Red Rice Cultivars of Assam, India

fat and ash content were estimated as per AOAC method, 1995 on dry weight basis.

\section{Calorific value}

Calorific value was estimated according to Osborn and Voogt, 1978 using following equation.

Calorific value $(\mathrm{kCal} / 100 \mathrm{~g})=(\mathrm{CP} \times 4)+(\mathrm{F} \times 9)+(\mathrm{CHO} \times 4)$ Where

$\mathrm{CP}$ means crude protein (\%); F means fat (\%) and $\mathrm{CHO}$ means carbohydrate content (\%).

\section{Mineral content}

The mineral contents of rice samples were determined following the method of AOAC (1995). The ash obtained as per method was dissolved in diluted $\mathrm{HCl}(1: 1)$, kept on a water bath at $100^{\circ} \mathrm{C}$ and the mixture was evaporated to dryness. $4 \mathrm{ml}$ of $\mathrm{HCl}$ and $2 \mathrm{ml}$ of glass distilled water were added, warmed and the acid soluble portion obtained after filtration was made up to $100 \mathrm{ml}$ with glass distilled water. This solution was used for estimation of Fe, $\mathrm{Zn}$ and Mn by atomic absorption spectrometer.

Extraction of rice samples for total phenols, total flavonoid content and antioxidant activity

The rice flour $(1.5 \mathrm{~g})$ was extracted $(1: 20 \mathrm{w} / \mathrm{v})$ at room temperature with $85 \%$ aqueous methanol for 30 min using a magnetic stirrer. The mixtures were centrifuged at $2500 \mathrm{~g}$ for $10 \mathrm{~min}$ and the supernatants were collected. The residues were re-extracted twice under the same conditions, resulting finally in $50 \mathrm{ml}$ crude extract.

\section{Determination of total phenolic content (TPC)}

The TPC of extracts was determined using the FolinCiocalteu reagent (Singleton et al. 1999). Extract $(120 \mu \mathrm{l})$ was added to $600 \mu \mathrm{l}$ of freshly diluted (10-fold) FolinCiocalteu reagent. $7.5 \%$ Sodium carbonate solution (980 $\mu \mathrm{l})$ was added to the mixture after 2 min reaction time. The absorbance of the resulting blue colour was measured at $760 \mathrm{~nm}$ against a blank after $5 \mathrm{~min}$ of reaction time at $50^{\circ} \mathrm{C}$. TPC was expressed as $\mathrm{mg}$ catechol equivalents per $100 \mathrm{~g}$ dry sample.

\section{Determination of total flavonoid content (TFC)}

The total flavonoid content was measured by colorimetric method as described previously (Wu and $\mathrm{Ng}, 2008$ ). Briefly, $0.5 \mathrm{ml}$ of sample extract was mixed with $2 \mathrm{ml}$ of distilled water, $0.15 \mathrm{ml}$ of $5 \%$ sodium nitrite and $0.15 \mathrm{ml}$ of $10 \%$ aluminium chloride, followed by reaction time of $6 \mathrm{~min}$. Then, $4 \% \mathrm{NaOH}(2 \mathrm{ml})$ was added to the mixture. After $15 \mathrm{~min}$ of incubation at room temperature, the absorbance of the mixture was measured at $510 \mathrm{~nm}$. All values were expressed as $\mathrm{mg}$ quercetin equivalents per $100 \mathrm{~g}$ dry sample.

Determination of 2,2-diphenyl-1-picrylhydrazyl (DPPH) radical scavenging activity

The DPPH free radical scavenging activity was determined following the procedure of Brand-williams et al. 1995. An aliquot of $0.3 \mathrm{ml}$ of diluted methanolic extract (2 times) was vigorously mixed with $1.5 \mathrm{ml}$ of freshly prepared $0.004 \%$ $\mathrm{DPPH}$ in methanol and held in the dark for $30 \mathrm{~min}$ at room temperature. The absorbance was then read at $517 \mathrm{~nm}$ against blank (only methanol). An equal mixture of methanol and $0.004 \% \mathrm{DPPH}$ in methanol was used as control. DPPH free radical scavenging ability was calculated by using the following formula:

Scavenging activity $(\%)=$

$$
\frac{\text { Absorbance of control - Absorbance of sample }}{\text { Absorbance of control }} \times 100
$$

\section{Statistical analysis}

All measurements were carried out in triplicate for each of the sample. All statistical analyses were carried out for the analysis of variance (ANOVA). Significance of the differences was ascribed at the 0.05 level for ANOVA.

\section{RESULTS AND DISCUSSION}

\section{Amylose content}

The amylose content (Table 1) in unpolished red rice cultivars of Assam varied significantly from 6.31-11.93\%. According to rice classification system of International Rice Research Institute (IRRI, 2009), most of the studied varieties were

Table1: Biochemical composition of red rice cultivars.

\begin{tabular}{|c|c|c|c|c|c|c|}
\hline $\begin{array}{l}\text { Name of } \\
\text { cultivars }\end{array}$ & $\begin{array}{c}\text { Amylose } \\
\text { content } \\
(\%)\end{array}$ & $\begin{array}{c}\text { Crude } \\
\text { fat } \\
(\%)\end{array}$ & $\begin{array}{l}\text { Crude } \\
\text { protein } \\
(\%)\end{array}$ & $\begin{array}{l}\text { Ash } \\
(\%)\end{array}$ & $\begin{array}{c}\text { Total } \\
\text { carbohydrates } \\
(\%)\end{array}$ & $\begin{array}{c}\text { Calorific } \\
\text { value } \\
(\mathrm{kCal} / 100 \mathrm{~g})\end{array}$ \\
\hline Rata boro & $8.99 \pm 0.52$ & $2.81 \pm 0.12$ & $11.34 \pm 0.32$ & $1.87 \pm 0.05$ & $83.99 \pm 0.49$ & $406.57 \pm 0.41$ \\
\hline Koujapuri & $9.05 \pm 0.03$ & $2.59 \pm 0.22$ & $4.36 \pm 0.17$ & $1.60 \pm 0.07$ & $91.45 \pm 0.46$ & $406.53 \pm 0.80$ \\
\hline Makhan boro & $6.58 \pm 0.21$ & $3.01 \pm 0.09$ & $3.96 \pm 0.05$ & $1.65 \pm 0.15$ & $91.38 \pm 0.29$ & $408.44 \pm 0.18$ \\
\hline Kaya boro & $9.07 \pm 0.04$ & $2.61 \pm 0.18$ & $10.87 \pm 0.02$ & $1.56 \pm 0.25$ & $84.96 \pm 0.45$ & $406.83 \pm 0.09$ \\
\hline Kola boro & $11.93 \pm 0.67$ & $2.69 \pm 0.21$ & $4.72 \pm 0.11$ & $1.49 \pm 0.15$ & $91.10 \pm 0.04$ & $407.49 \pm 1.63$ \\
\hline Basanta bahar & $8.04 \pm 0.12$ & $2.68 \pm 0.14$ & $12.31 \pm 0.21$ & $1.64 \pm 0.19$ & $83.37 \pm 0.26$ & $406.84 \pm 1.48$ \\
\hline Dadratai & $6.31 \pm 0.14$ & $2.71 \pm 0.12$ & $13.23 \pm 0.09$ & $1.73 \pm 0.11$ & $82.33 \pm 0.33$ & $406.61 \pm 0.17$ \\
\hline Binnapali & $9.68 \pm 0.15$ & $2.61 \pm 0.19$ & $4.77 \pm 0.08$ & $1.63 \pm 0.18$ & $90.99 \pm 0.07$ & $406.51 \pm 1.65$ \\
\hline Buria makra & $9.23 \pm 0.07$ & $2.72 \pm 0.14$ & $4.97 \pm 0.06$ & $1.53 \pm 0.23$ & $90.78 \pm 0.15$ & $407.45 \pm 1.61$ \\
\hline Hal aus & $7.58 \pm 0.22$ & $3.09 \pm 0.02$ & $9.35 \pm 0.18$ & $1.46 \pm 0.04$ & $86.1 \pm 0.20$ & $409.63 \pm 0.23$ \\
\hline
\end{tabular}


Nutritional Composition, Mineral Content and Antioxidant Properties of Unpolished Red Rice Cultivars of Assam, India

categorized into very low (2-9\%) and low amylose (10-20\%) content. Similar results were also reported by Reddy et al. 2016. The cooking quality of rice is dependent on amylose content (Yadav et al. 2007). Cooked rice with low amylose content is soft and sticky.

\section{Proximate composition}

\section{Fat content}

Crude fat contents were found between 2.59-3.09\% (Table 1). Fat content in this study were of comparatively somewhat similar and in the range values reported by Sompong et al. 2011, Gunaratne et al. 2013, Kariyawasama et al. 2016, Reddy et al. 2017. Fat content influences the taste of cooked rice as rice with high fat content tends to be tastier (Hirokadzu et al. 1979).

\section{Protein content}

Crude protein content varied significantly (3.96-13.23\%) among the different red rice cultivars whereas Dadratai exhibited the highest protein content. Protein content influences the nutritional quality of rice (Sompong et al. 2011). Rice having more than $10 \%$ total crude protein is considered to be of high protein type (Resurrection et al. 1979). The protein content of cultivars Rata boro, Kaya boro, Basanta bahar, Dadratai was appreciably high (>10\%). Protein content in this study was comparable to the values found by Kariyawasama et al. 2016, Reddy et al. 2017, but higher than the reports of Samyor et al. 2010.

\section{Ash content}

Ash value ranged from $1.46-1.87 \%$ in the cultivars (Table 1). The results were similar to those reported values of Sompong et al. 2011, Kariyawasama et al. 2016, Reddy et al. 2017 and higher than the values reported by Samyor et al. 2015 . Ash content gives an idea about the mineral contents of a food sample (Mbatchou and Dawda, 2013) and also high percentage of ash content may affect the sensory quality of the rice (Julliano, 1985).

\section{Carbohydrate content}

The carbohydrate content of all the cultivars ranged significantly from $82.33-91.38 \%$ (Table 1 ). All the rice cultivars exhibited higher amount of carbohydrate than the reports of Reddy et al. 2017, Sompong et al. 2011. However, the carbohydrate content of all the rice cultivars was more than $80 \%$ and thus all of them are considered as good source of carbohydrates.

\section{Calorific value}

Calorific value measures the available amount of energy obtained from food via cellular respiration (Thomas et al. 2013). Calorific values of rice cultivars obtained in the study found higher than the values of calorie contents reported by Kariyawasama et al. 2016. All the studied cultivars showed high energy values. Therefore, consumption of these nutrient rich rice cultivars may play a vital role in decreasing nutritional deficiencies.

\section{Mineral compositions}

\section{Fe content}

Red rice cultivars had Fe content in the range of 0.72-3.37 $\mathrm{mg} / 100 \mathrm{~g}$ (Table 2). The Fe content of red rice cultivars was significantly different among all the selected rice varieties. Binnapali had the highest iron content. Fe content in all red rice cultivars is higher than the reported values of Yodmanee et al. 2011. Grain color is related to iron content and Iron content tends to be higher in colored (red and black) rice varieties than in white rice varieties (Meng et al. 2005).

\section{Zn content}

$\mathrm{Zn}$ content varied significantly among the selected red rice cultivars. Koujapuri had the highest $\mathrm{Zn}$ content of $5.85 \mathrm{mg} /$ $100 \mathrm{~g}$ and the lowest $\mathrm{Zn}$ content was found in Hal aus (1.84 $\mathrm{mg} / 100 \mathrm{~g}$ ). Similar range of values were also reported by Anuradha et al. 2012, Reddy et al. 2017. Zn have been found to be involved in free radicals scavenging enzyme systems in rice, as components of the superoxide dismutase (Dehury et al. 2013).

\section{Mn content}

Mn content ranged from $0.64-2.52 \mathrm{mg} / 100 \mathrm{~g}$ and varied significantly among the red rice cultivars. Rata boro contained the highest $\mathrm{Mn}$ content. Mn content of present

Table 2: Mineral content of red rice cultivars.

\begin{tabular}{lccc}
\hline Cultivars & $\begin{array}{l}\text { Fe content } \\
(\mathrm{mg} / 100 \mathrm{~g})\end{array}$ & $\begin{array}{c}\text { Zn content } \\
(\mathrm{mg} / 100 \mathrm{~g})\end{array}$ & $\begin{array}{l}\text { Mncontent } \\
(\mathrm{mg} / 100 \mathrm{~g})\end{array}$ \\
\hline Rata boro & $2.29 \pm 0.12$ & $2.53 \pm 0.24$ & $2.52 \pm 0.25$ \\
Koujapuri & $1.47 \pm 0.25$ & $5.85 \pm 0.28$ & $2.10 \pm 0.22$ \\
Makhan boro & $1.17 \pm 0.12$ & $2.87 \pm 0.21$ & $1.85 \pm 0.22$ \\
Kaya boro & $2.00 \pm 0.14$ & $2.17 \pm 0.11$ & $1.62 \pm 0.18$ \\
Kola boro & $0.95 \pm 0.02$ & $5.34 \pm 0.20$ & $1.97 \pm 0.28$ \\
Basanta bahar & $1.62 \pm 0.18$ & $2.33 \pm 0.22$ & $1.79 \pm 0.14$ \\
Dadratai & $0.81 \pm 0.07$ & $4.33 \pm 0.15$ & $0.78 \pm 0.10$ \\
Buriamakra & $0.72 \pm 0.11$ & $3.47 \pm 0.21$ & $2.12 \pm 0.13$ \\
Binnapali & $3.37 \pm 0.14$ & $5.67 \pm 0.16$ & $1.27 \pm 0.17$ \\
Hal aus & $1.55 \pm 0.23$ & $1.84 \pm 0.34$ & $0.64 \pm 0.10$ \\
\hline
\end{tabular}

Table 3: Total polyphenol, flavonoid content and antioxidant activity of red rice cultivars.

\begin{tabular}{lccc}
\hline $\begin{array}{l}\text { Name } \\
\text { of } \\
\text { cultivars }\end{array}$ & $\begin{array}{c}\text { Total } \\
\text { Polyphenol } \\
\text { content } \\
(\mathrm{mg} / 100 \mathrm{~g})\end{array}$ & $\begin{array}{c}\text { Total } \\
\text { flavonoid } \\
\text { content } \\
(\mathrm{mg} / 100 \mathrm{~g})\end{array}$ & $\begin{array}{c}\text { DPPH free } \\
\text { radical } \\
\text { scavenging } \\
\text { activity }(\%)\end{array}$ \\
\hline Rata Boro & $905.57 \pm 30.81$ & $862.99 \pm 2.36$ & $82.27 \pm 0.26$ \\
Koujapuri & $863.49 \pm 32.78$ & $732.95 \pm 7.54$ & $81.81 \pm 0.69$ \\
Makhan boro & $884.56 \pm 63.98$ & $691.49 \pm 16.65$ & $83.12 \pm 0.22$ \\
Kaya boro & $1021.04 \pm 7.11$ & $639.68 \pm 4.58$ & $82.71 \pm 0.10$ \\
Kola Boro & $920.63 \pm 13.69$ & $565.06 \pm 31.33$ & $81.39 \pm 0.43$ \\
Basanta bahar & $336.49 \pm 46.55$ & $127.51 \pm 7.03$ & $33.33 \pm 0.82$ \\
Dadratai & $806.80 \pm 21.73$ & $723.31 \pm 52.02$ & $84.24 \pm 0.08$ \\
Binnapali & $520.66 \pm 23.87$ & $252.26 \pm 4.40$ & $54.91 \pm 0.82$ \\
Hal aus & $1357.22 \pm 77.51$ & $896.37 \pm 29.91$ & $80.60 \pm 0.27$ \\
\hline
\end{tabular}


Nutritional Composition, Mineral Content and Antioxidant Properties of Unpolished Red Rice Cultivars of Assam, India

study was comparable to the reported values of Reddy et al. 2017, Mudoi and Das, 2019.

\section{TPC content}

TPC of red rice cultivars is presented in Table 3. Significant differences in TPC were observed within the red rice cultivars. Hal aus $(1357.22 \mathrm{mg} / 100 \mathrm{~g})$ showed the highest TPC, whereas the lowest value was noted for Basanta bahar $(336.49 \mathrm{mg} / 100 \mathrm{~g})$. TPC values of selected red rice cultivars were higher than the reported values of Yodmanee et al. 2011, Gunaratne et al. 2013, Samyor et al. 2015.

\section{TFC content}

TFC in red rice cultivars ranged from 127.51 to $896.37 \mathrm{mg} /$ $100 \mathrm{~g}$ (Table 3). The highest TFC was noted in Hal aus while the lowest TFC was observed for Basanta bahar. All the cultivars exhibited higher levels of TFC than those of previous studies of red rice varieties reported by Huang and Ng, 2012 and Reddy et al. 2017.

\section{Antioxidant properties}

The antioxidant activities of red rice cultivars were analyzed by DPPH assay. All the red rice cultivars showed significant scavenging activity towards the free radical. Dadratai exhibited the highest activity (84.24\%), while the lowest was observed for Basanta bahar (33.33\%). Higher antioxidant properties are due to higher phenolic compounds in the Rice bran (Zhang et al. 2010). Several authors reported that red rice cultivars have higher free radical scavenging activity than black- and white-hulled rice cultivars (Finocchiaro et al. 2010, Walter et al. 2013).

\section{CONCLUSION}

The red rice cultivars in the present study contain a significant amount of antioxidants including phenolic and flavonoids. Therefore, the present results suggest that red rice cultivars may be utilized as an effective antioxidant source due to its radical scavenging activities and phenolic compounds. The studied red rice cultivars are good source of $\mathrm{Fe}, \mathrm{Zn}$ and $\mathrm{Mn}$. The traditional red rice cutivars containing high proximate composition can be used for developing functional foods and also may be used as important genetic sources for breeding the excellent varieties for high quality of rice production.

\section{ACKNOWLEDGEMENT}

The first author is grateful to Department of Biotechnology, Govt of India for offering DBT Research Associateship.

\section{REFERENCES}

Abdel-Aal, E.S.M., Young, J.C. and Rabalski, I. (2006). Anthocyanins composition in black, blue, pink, purple and red cereal grains. Journal of Agricultural and Food Chemistry. 54: 4696-04.

Anuradha, K., Agarwal, S., Batchu, A.K., Babu, A.P., Mallikarjuna Swamy B.P., Longvah T. and Sarla N. (2012). Evaluating rice germplasm for iron and zinc concentration in brown rice and seed dimensions. Journal of Phytology. 4: 19-25.
AOAC, Association of Official Analytical Chemists. (1995). Official Methods of Analysis of the AOAC International (sixteenth ed.). Washington, D.C.

Brand-williams, W., Cuvelier M.E. and Berset, C. (1995). Use of free radical method to evaluate antioxidant activity. Lebensmittel Wissenschaft and Technologie. 28: 25-30.

Chaudhary, R.C. (2003). Speciality rices of the world: Effect of WTO and IPR on its production trend and marketing. Journal of Food, Agriculture and Environment. 1: 34-41.

Dehury, B., Sarma, K., Sarmah, R., Sahu, J., Sahoo, S., Sahu, M., Sen, P., Modi, M., Sharma, G., Dutta, M., Choudhury M. and Barooah M. (2013). In silico analyses of superoxide dismutases (SODs) of rice (Oryza sativa L.). J. Plant Biochem. Biotechnol. 22: 150-56.

Finocchiaro, F., Ferrari, B. and Gianinetti, A. (2010). A study of biodiversity of flavonoid content in the rice caryopsis evidencing simultaneous accumulation of anthocyanins and proanthocyanidins in a black-grained genotype. Journal of Cereal Science. 51: 28-34.

Gunaratne, A., Wu, K., Li, D., Bentota, A., Corke, H. and Cai, Y-Z. (2013). Antioxidant activity and nutritional quality of traditional red-grained rice varieties containing proanthocyanidins, Food Chemistry. 138: 1153-61.

Hirokadzu, T., Harue, T. and Keishi, F. (1979). Influence of cropping season on lipid content and fatty acid composition of lowland non-glutinous brown rice. Jpn. J. Crop Sci. 48: 371-77.

Huang, S.H. and Ng, L.T. (2012). Quantification of polyphenolic content and bioactive constituents of some commercial rice varieties in Taiwan. Journal of Food Composition and Analysis. 26: 122-27.

IRRI. (2009). Rice Quality Characteristics of Milled Rice from http:// www.knowledgebank.irri.org/millingprocess/index.php/ ricequalitymainmenu281/quality-characteristics-ofmilled-rice-mainmenu-283.

Itani, T., Tamaki, M., Arai, E. and Horino, T. (2002). Distribution of amylose, nitrogen and minerals in rice kernels with various characters. Journal of Agricultural Food Chemistry. 50: $5326-32$.

Juliano, B.O. (1985). Factors affecting nutritional properties of rice protein. Trans Nat Acad Sci Technol. 7: 205-16.

Kariyawasama, T.I., Godakumburaa, P.I., Prashanthaa, M.A.B., Premakumarab, G.A.S. (2016). Proximate composition, calorie content and heavy metals (As, $\mathrm{Cd}, \mathrm{Pb}$ ) of selected Sri Lankan traditional rice (Oryza sativa L.) varieties. Procedia Food Science. 6: 253-56.

Mbatchou, V.C. and Dawda, S. (2013). The nutritional composition of four rice varieties grown and used in different food preparations in Kassena-Nankana district, Ghana. Int J. Res. Chem. Environ. 3: 308-15.

Meng, F., Wei, Y. and Yang, X. (2005). Iron content and bioavailability in rice. J. Trace Elem. Med. Biol. 18: 333-38.

Mira, N.V.M., Isabel, L.M., Cristina de Simone, C.I.P., Ursula, M.L.M. (2009). Comparative study of phenolic compounds in different Brazilian rice (Oryza sativa L.) genotypes. Journal of Food Composition and Analysis. 22: 405-09.

Mudoi, T. and Das, P. (2018). Nutritional composition of traditional colored rice cultivars of Assam, India. Bull. Env. Pharmacol. Life Sci. 7: 10-14. 
Mudoi, T. and Das, P. (2019). A Study on Phytochemicals and Mineral Content of Indigenous Red Rice of Assam, India. Int. J. Curr, Microbiol. App. Sci. 8: 1-12.

Osborn, D.R. and Voogt, P. (1978). Calculation of calorific value. In: The Analysis of Nutrients in Foods. New York, USA: Academic Press: 239-40.

Reddy, C. K., Kimi, L. and Haripriya, S. (2016). Variety difference in molecular structure, functional properties, phytochemical content and antioxidant capacity of pigmented rice. Food Measure. 10: 605-13.

Reddy, C.K., Kimi, L., Haripriya, S., Nayoung Kang, N. (2017). Effects of polishing on proximate composition, physicochemical characteristics, mineral composition and antioxidant properties of pigmented rice. Rice Science. 24: $241-52$.

Resurrection, A.P., Juliano, B.O. and Tanaka, Y. (1979). Nutritional content and distribution in milling fractions of rice grains. J. Sci Food Agric. 30: 475-81.

Saikia, S., Dutta, H., Saikia, D., Mahanta, C.L. (2012). Quality characterisation and estimation of phytochemicals content and antioxidant capacity of aromatic pigmented and non-pigmented rice varieties. Food Research International. 46: 334-40.

Samyor D., Deka, S.C. and Das. A.B. (2016). Phytochemical and antioxidant profile of pigmented and nonpigmented rice cultivars of Arunachal Pradesh, India. International Journal of Food Properties. 19: 1104-14.

Shao, Y., Xu, F., Sun, X., Bao, J. and Beta, T. (2014). Identification and quantification of phenolic acids and anthocyanins as antioxidants in bran, embryo and endosperm of white, red and black rice kernels (Oryza sativa L.). Journal of Cereal Science. 59: 211-18.

Singleton, V.L., Orthofer, R. and Lamuela-Raventos, R.M. (1999). Analysis of total phenols and other oxidation substrates and antioxidants by means of Folin-Ciocalteu reagent. Meth. Enzymol. 299: 152-78.

Sompong, R., Siebenhandl-Ehn, S., Linsberger-Martin, G. and Berghofer, E. (2011). Physicochemical and antioxidative properties of red and black rice varieties from Thailand, China and Sri Lanka. Food Chemistry. 124: 132-40.
Sowbahagya, C.M. and Bhattacharya, K.R. (1979). Simplified determination of amylose in milled rice. Starch-Starke. 31: $159-63$

Suzuki, M., Kimura, T., Yamagish, K., Shinmoto, H., Yamaki, K. (2004). Nippon ShokuhinKagakuKogakuKaishi, 51: 424. the AOAC International (sixteenth ed.). Washington, D.C.

Thomas, R., Wan-Nadiah, W.A. and Bhat, R. (2013). Physiochemical properties, proximate composition and cooking qualities of locally grown and imported rice varieties marketed in Penang, Malaysia. Int Food Res J. 20: 134551.

Ti, H.H., Li, Q., Zhang, R.F., Zhang, M.W., Deng, Y.Y., Wei, Z.C., Chi, J. W. and Zhang, Y. (2014). Free and bound phenolic profiles and antioxidant activity of milled fractions of different indica rice varieties cultivated in southern China. Food Chem. 159: 166-74.

Walter, M., Marchesan, E., Massoni, P.F.S., Silva, L.P. , Sartori, G.M.S. and Ferreira, R.B. (2013). Antioxidant properties of rice grains with light brown, red and black pericarp colors and the effect of processing. Food Research International. 50: 698-03.

Wu, S. J. and $\mathrm{Ng}$, L.T. (2008). Antioxidant and free radical scavenging activities of wild bitter melon (Momordica charantia Linn. var. abbreviate Ser.) in Taiwan. LWT-Food Sci. Technol. 41: 323-30.

Yadav, R.B., Khatkar, B.S. and Yadav, B.S. (2007). Morphological, physico-chemical and cooking properties of some Indian rice (Oryza sativa L.) cultivars. J. Agric. Technol. 3: 203-10.

Yawadio, R., Tanimori, S. and Morita, N. (2007). Identification of phenolic compounds isolated from pigmented rices and their aldose reductase inhibitory activities. Food Chemistry. 101: 1616-25.

Yodmanee, S., Karrila, T.T. and Pakdeechanuan, P. (2011). Physical, chemical and antioxidant properties of pigmented rice grown in Southern Thailand. International Food Research Journal. 18: 901-06.

Zhang, M.W., Zhang, R.F., Zhang, F.X. and Liu, R.H. (2010). Phenolic profiles and antioxidant activity of black rice bran of different commercially available varieties. Journal of Agricultural and Food Chemistry. 58: 7580-87. 